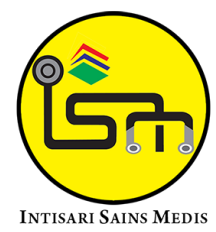

Published by Intisari Sains Medis

\title{
Karakteristik faktor penyebab hiperbilirubinemia pada neonatus di RSIA Puri Bunda Tabanan, Bali Tahun 2021
}

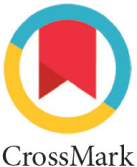

CrossMark

\author{
Intan Astariani ${ }^{1 *}$, I Wayan Dharma Artana ${ }^{2,3}$, Ni Made Rini Suari ${ }^{1,2}$
}

\section{ABSTRACT}

Background: Neonatal hyperbilirubinemia is a clinical problem that often occurs in neonates, $60 \%$ occurs in term neonates and $80 \%$ in preterm neonates.. There are non pathological and pathological hyperbilirubinemia. Unconjugated hyperbilirubinemia caused by 4 board groups, which are increased bilirubin production, deficiency of hepatic uptake, impaired bilirubin conjugation, and increased enterohepatic circulation. The purpose of this study was to determine the characteristics of the factors causing hyperbilirubinemia.

Methods: This study used a restrospective crosssectional method by taking 1 year data, from June 2020 until May 2021. Amount of samples was 146 neonates with diagnosis of hyperbilirubinemia and receiving intensive phototherapy treatment in the Intermediate Room and Neonatal HCU at Puri Bunda Tabanan Mother and Child Hospital. The causative factors collected were

ABO incompatibility, prematurity, neonatal asphyxia, breastfeeding jaundice, breastmilk jaundice, low birth weight baby, cephal hematome, and neonatal sepsis. Data collected through medical record and analyzed, subsequently explained descriptively with table.

Result: The result show that from 146 samples that met the inclusion criteria, the most causative factor of hyperbilirubinemia was ABO incompatibility 29 (19.9\%), prematurity 16 (11\%), low birth weight 15 (10.3\%), breastfeeding jaundice $15(10.3 \%)$, neonatal sepsis $15(10.3 \%)$, breastmilk jaundice $12(8.2 \%)$, neonatal asphyxia 7 (4.8\%), and no sample with cephal hematome.

Conclusion: Factors causing hyperbilirubinemia found at Puri Bunda Tabanan Mother and Child Hospital were ABO icompatibility as the most common cause and neonatal asphyxia as the least cause.

Keywords: ABO incompatibility, causative factors, hyperbilirubinemia, neonatal asphyxia, prematurity. Cite This Article: Astariani, I., Artana, I.W.D., Suari, N.M.R. 2021. Karakteristik faktor penyebab hiperbilirubinemia pada neonatus di RSIA Puri Bunda Tabanan, Bali Tahun 2021. Intisari Sains Medis 12(3): 917-920. D0I: 10.15562/ ism.v12i3.1174

${ }^{1}$ RSIA Puri Bunda Tabanan, Tabanan, Bali, Indonesia; 2RSIA Puri Bunda, Denpasar, Bali, Indonesia; ${ }^{3}$ Staff Departemen/KSM IImu Kesehatan Anak, Rumah Sakit Umum Pusat (RSUP) Sanglah, Denpasar, Bali, Indonesia;

\section{*Korespondensi:}

Intan Astariani;

RSIA Puri Bunda Tabanan, Tabanan, Bali, Indonesia; astariani.intan@gmail.com

Diterima: 13-10-2021

Disetujui: 03-12-2021

Diterbitkan: 21-12-2021

\section{ABSTRAK}

Pendahuluan: Hiperbilirubinemia neonatal merupakan permasalahan klinis yang sering terjadi pada neonatus, sekitar $60 \%$ terjadi pada neonatus aterm dan $80 \%$ pada neonatus preterm. Kernicterus sebagai komplikasi dari hiperbilirubinemia memiliki angka kematian 10\% dan morbiditas jangka panjang $70 \%$. Hiperbilirubinemia ada yang non patologis dan patologis. Unconjugated hyperbilirubinemia disebabkan oleh 4 kelompok besar yaitu peningkatan produksi bilirubin, defisiensi uptake hepar, gangguan konjugasi bilirubin, dan peningkatan sirkulasi enterohepatik. Tujuan dari penelitian ini adalah untuk mengetahui karakteristik faktor penyebab hiperbilirubinemia. Metode: Penelitian ini menggunakan metode crosssectional retrospective dengan mengambil data selama 1 tahun yaitu periode Juni 2020-Mei 2021. Jumlah sampel sebanyak 146 neonatus dengan diagnosis hiperbilirubinemia dan mendapatkan tatalaksana fototerapi di ruang Intermediate dan HCU Neonatus di RSIA Puri Bunda Tabanan. Faktor penyebab yang dikumpulkan yaitu inkompatibilitas $A B 0$, prematuritas, asfiksia neonatorum, breastfeeding jaundice, breastmilk jaundice, BBLR, cephal hematoma, dan sepsis neonatorum. Data dikumpulkan melalui rekam medis dan dianalisa untuk kemudian disajikan secara deskriptif.

Hasil: Dari 146 sampel yang memenuhi kriteria inklusi, didapatkan penyebab pertama yaitu inkompatibilitas ABO sebanyak $29(19,9 \%)$, prematuritas sebanyak $16(11 \%)$, BBLR sebanyak $15(10,3 \%)$, breastfeeding jaundice sebanyak $15(10,3 \%)$, sepsis neonatorum sebanyak 15 (10,3\%), breastmilk jaundice sebanyak 
$12(8,2 \%)$, asfiksia neonatorum sebanyak 7 (4,8\%), dan tidak ada penyebab berupa cephal hematoma yang ditemukan.

Simpulan: Faktor penyebab hiperbilirubinemia yang didapatkan di RSIA Puri Bunda Tabanan yaitu inkompatibilitas $\mathrm{ABO}$ sebagai penyebab terbanyak dan asfiksia neonatorum sebagai penyebab paling sedikit.

Kata kunci: asfiksia neonatorum, faktor penyebab, hiperbilirubinemia, inkompatibilitas $A B O$, prematuritas. Sitasi Artikel ini: Astariani, I., Artana, I.W.D., Suari, N.M.R. 2021. Karakteristik faktor penyebab hiperbilirubinemia pada neonatus di RSIA Puri Bunda Tabanan, Bali Tahun 2021. Intisari Sains Medis 12(3): 917-920. D0I: 10.15562/ ism.v12i3.1174

\section{PENDAHULUAN}

Hiperbilirubinemia merupakan peningkatan jumlah bilirubin yang terakumulasi di darah dimana kadar bilirubin serum total $\geq 5 \mathrm{mg} / \mathrm{dL}$ (86 $\mu \mathrm{mol} / \mathrm{L})$ dan ditandai dengan jaundice yaitu pewarnaan kuning yang terlihat di kulit, sklera mata, kuku dan mukosa akibat penumpukan bilirubin tak terkonjugasi pada jaringan. Hiperbilirubinemia merupakan suatu masalah yang sangat sering terjadi pada neonatus. Sekitar $60 \%$ neonatus $>35$ minggu mengalami hiperbilirubinemia dan sekitar $80 \%$ pada neonatus <35 minggu. ${ }^{1,2}$ Di Indonesia, angka kejadian ikterus pada bayi cukup bulan dari RSUP Dr. Cipto Mangunkusumo, RSUP Dr. Sardjito, RS Dr. Soetomo dan RS Dr. Kariadi bervariasi antara $13.7 \%$ - 85\%. ${ }^{3}$ Di RSIA Puri Bunda Tabanan sendiri, hiperbilirubinemia menduduki posisi utama sebagai diagnosis rawat inap terbanyak di ruang Intermediate dan HCU Neonatus.

Terdapat dua klasifikasi hiperbilirubinemia neonatus menurut penyebabnya, yaitu hiperbilirubinemia non-patologis dan patologis. Hiperbilirubinemia non-patologis terdiri dariikterusfisiologis, breastfeedingjaundice dan breastmilkjaundice, serta prematuritas. Hiperbilirubinemia patologis terdiri dari unconjugated hyperbilirubinemia dan conjugated hyperbilirubinemia. Unconjugated hyperbilirubinemia disebabkan oleh 4 kelompok besar yaitu peningkatan produksi bilirubin, defisiensi uptake hepar, gangguan konjugasi bilirubin, dan peningkatan sirkulasi enterohepatik. Beberapa faktor risiko dari hiperbilirubinemia antara lain inkompatibilitas $\mathrm{ABO}$ dan Rhesus, defisiensi G6PD, cephal hematome, breastmilk jaundice, prematuritas, sepsis neonatorum, asfiksia neonatorum, breastfeeding jaundice, ataupun obatobatan seperti sulfisoxazole, streptomycin, benzyl alcohol, dan chloramfenicol. ${ }^{4}$

Kernikterus sebagai komplikasi dari hiperbilirubinemia, merupakan toksisitas bilirubin dimana terjadi akumulasi bilirubin indirek di ganglia basalis dan hippocampus. Kernikterus dapat menimbulkan sequele yang bersifat kronik maupun permanen seperti cerebral palsy, tuli, kelumpuhan dan displasia gigi yang sangat berdampak pada kualitas kehidupan. Kernikterus dapat terjadi apabila hiperbilirubinemia tidak tertangani dengan baik. Angka kematian kernikterus cukup tinggi yaitu sekitar 10\% dan morbiditas jangka panjang sekitar $70 \%{ }^{1,5,6,7,8}$

Melihat tingginya angka kejadian hiperbilirubinemia dan kecenderungan untuk menimbulkan komplikasi yang bersifat kronis dan permanen bila tidak tertangani dengan tepat, maka penelitian untuk mengetahui karakteristik faktor penyebab hyperbilirubinemia dibutuhkan. Penelitian ini bertujuan untuk mengetahui karakteristik faktor penyebab hyperbilirubinemia.

\section{METODE}

Penelitian ini merupakan penelitian cross sectional dengan mengambil data secara retrospektif dari rekam medis pasien dengan diagnosis hiperbilirubinemia di ruang intermediate dan $\mathrm{HCU}$ neonatus RSIA Puri Bunda Tabanan. Sampel dikumpulkan dengan metode total sampling. Didapatkan total 146 sampel yang memenuhi kriteria inklusi. Kriteria Inklusi adalah pasien dengan diagnosis utama maupun sekunder hiperbilirubinemia di ruang Intermediate dan $\mathrm{HCU}$ Neonatus RSIA Puri Bunda Tabanan pada bulan Juni 2020 hingga Mei 2021 dengan batasan usia 28 hari. Kriteria sampel yang dieksklusi adalah pasien dengan data rekam medis yang tidak lengkap dan tidak dapat ditelusuri. Karakteristik penyebab yang ditelusuri dalam penelitian ini antara lain inkompatibilitas $\mathrm{ABO}$ prematuritas, asfiksia neonatorum, breastfeeding jaundice, breastmilk jaundice, BBLR, cephal hematome, dan sepsis neonatorum.

Data dianalisis univariat menggunakan Statistical Product and Service Solution (SPSS) 22 for windows. Interpretasi data dilakukan dengan penjabaran secara deskriptif dan hasil penelitian disajikan dalam bentuk tabel.

\section{HASIL}

Selama periode penelitian pada bulan Juni 2020 hingga Mei 2021, peneliti berhasil mengumpulkan sebanyak 150 pasien dengan diagnosa hiperbilirubinemia sesuai dengan data yang tercatat di register pasien ruang Intermediate dan HCU Neonatus RSIA Puri Bunda Tabanan. Sebanyak 146 pasien dimasukkan sebagai sampel dan sisanya diekslusi. Karakteristik faktor penyebab hiperbilirubinemia yang didapatkan disajikan dalam Tabel 1.

Distribusi faktor penyebab hiperbilirubinemia di RSIA Puri Bunda Tabanan, didapatkan penyebab paling tinggi adalah inkompatibilitas ABO sebanyak 29 sampel (19,9\%), penyebab kedua terbanyak yaitu prematuritas sebanyak 16 sampel (11\%), sedangkan breastfeeding jaundice, BBLR, dan sepsis neonatorum sama-sama menjadi penyebab ketiga dengan proporsi yang sama yaitu 15 sampel (10,3\%). Breastmilk jaundice menjadi penyebab keempat dengan 12 
Tabel 1. Karakteristik Faktor Penyebab.

\begin{tabular}{ccc}
\hline Faktor Penyebab & Frekuensi & $\%$ \\
\hline Inkompatibilitas ABO & 29 & 19,9 \\
Prematuritas & 16 & 11 \\
BBLR & 15 & 10,3 \\
Breast Feeding Jaundice & 15 & 10,3 \\
Sepsis Neonatorum & 15 & 10,3 \\
Breast Milk Jaundice & 12 & 8,2 \\
Asfiksia Neonatorum & 7 & 4,8 \\
Cephal Hematoma & 0 & 0 \\
\hline
\end{tabular}

sampel (8,2\%), asfiksia neonatorum sebagai penyebab kelima dengan 7 sampel $(4,8 \%)$ dan tidak ada sampel dengan penyebab cephal hematome.

\section{PEMBAHASAN}

Pada penelitian ini didapatkan faktor penyebab utama adalah inkompatibilitas ABO dengan jumlah sampel 29 dan persentase $19,9 \%$. Inkompatibilitas golongan darah $\mathrm{ABO}$ ibu dan janin, dimana ibu memiliki golongan darah $\mathrm{O}$, sementara bayi memiliki golongan darah A atau B terjadi pada 15-20\% kehamilan. Penyakit hemolitik dapat berkembang pada $10 \%$ bayi baru lahir. Penelitian Akgul dkk tahun 2013, mendapatkan bahwa golongan darah bayi baik $\mathrm{A}$ ataupun B tidak berpengaruh pada tingkat keparahan hemolytic jaundice pada inkompatibilitas $\mathrm{ABO}$ dengan nilai p > 0,05. ${ }^{8}$ Penelitian observasional analitik Maulida dkk tahun 2021, dengan metode cross sectional mendapatkan bahwa terdapat hubungan yang bermakna antara kejadian hiperbilirubinemia dengan inkompatibilitas $\mathrm{ABO}$ dengan nilai $\mathrm{p}=$ $0.001 .^{9}$

Faktor penyebab terbanyak kedua yaitu prematuritas, dimana terdapat 16 sampel dengan persentase $11 \%$. Penelitian lain mendapatkan bahwa adanya pengaruh faktor risiko prematuritas terhadap kejadian hiperbilirubinemia. Hiperbilirubinemia lebih cepat terjadi pada bayi preterm dan berlangsung lebih lama dikarenakan oleh sel hati yang masih imatur, uptake dan konjugasi bilirubin yang lambat, dan sirkulasi enterohepatik yang meningkat. ${ }^{10}$ Penelitian Olusanya dkk tahun 2015 dan Devi dkk tahun 2017 juga menyatakan bahwa prematuritas mempengaruhi kejadian hiperbilirubinemia dengan nilai $\mathrm{p}$ sebesar
Breastfeeding jaundice (BFJ), Berat Badan Lahir Rendah (BBLR), dan sepsis neonatorum menjadi faktor penyebab ketiga dimana ketiganya memiliki persentase yang sama yaitu 10,3\% dan didapatkan pada 15 sampel. Kondisi breastfeeding jaundice atau suboptimal intake jaundice, paling sering terjadi dalam 1 minggu pertama usia neonatus saat bayi menyusui secara langsung. Meningkatkan frekuensi menyusui menjadi 8 hingga 12 kali dalam sehari dapat mengurangi risiko jaundice. $^{13}$

Penelitian yang dilakukan oleh Parwata dkk tahun 2017, mendapatkan bahwa BFJ menjadi penyebab tertinggi terjadinya hiperbilirubinemia di RSUP Sanglah tahun 2017, sementara sepsis neonatorum menjadi penyebab tersedikit. ${ }^{7}$

Penelitian oleh Olusanya dkk tahun 2015 dengan studi meta analitik, membuktikan bahwa sepsis neonatorum meningkatkan risiko terjadinya hiperbilirubinemia yang berat dengan nilai $\mathrm{p}>0001$, OR 9.15 dengan 95\% CI: 2.78 - 30.10. ${ }^{12}$ Pasien dengan sepsis akan meningkatkan destruksi eritrosit, sehingga terjadi pemecahan hemoglobin yang berlebihan di dalam sistem retikuloendothelial yang menyebabkan penumpukan bilirubin indirek. ${ }^{14}$ Penelitian multicenter, prospective, crosssectional, observasi klinis yang dilakukan oleh Aynalem dkk tahun 2020 pada bayi preterm, mendapatkan bahwa sepsis neonatorum berhubungan secara signifikan dengan hiperbilirubinemia neonatus. ${ }^{15}$

Secara teori, BBLR dikaitkan dengan prematuritas yang memungkinkan terjadinya imaturitas pada organ hati bayi. Imaturitas organ hati ini menyebabkan terganggunya proses konjugasi bilirubin indirek menjadi bilirubin direk dan tidak

\section{$<0.0001 .^{11,12}$}

terpenuhinya kadar albumin darah yang berfungsi sebagai transportasi bilirubin dari jaringan ke hati. Penelitian Puspita tahun 2018 dan penelitian Devi dkk tahun 2017 juga menyatakan bahwa bayi dengan berat badan lahir rendah meningkatkan kejadian hiperbilirubinemia. ${ }^{11,16}$ Namun, pada penelitian observasional analitik yang dilakukan oleh Wijaya dkk tahun 2019 dengan metode case control didapatkan tidak ada hubungan yang signifikan antara BBLR dan hiperbilirubinemia, yang juga dikuatkan dengan penelitian lain dimana dinyatakan bahwa berat badan lahir rendah tidak mempengaruhi kejadian hiperbilirubinemia. ${ }^{3,11}$

Penyebab keempat yang didapatkan adalah breast milk jaundice (BMJ), dimana BMJ didapatkan pada 12 sampel dengan persentase 8,2\%. BMJ seringkali muncul pada minggu kedua atau lebih usia neonatus dan dapat tetap berlangsung dalam beberapa minggu. Penelitian yang dilakukan oleh Parwata dkk tahun 2019 mendapatkan bahwa BMJ sebagai faktor penyebab terendah kejadian ikterus neonatorum di RSUP Sanglah. ${ }^{7}$ Penelitian Huang dkk tahun 2004, mendapatkan bahwa menyusui merupakan temuan paling banyak pada kasus hiperbilirubinemia. Mekanisme bagaimana ASI dapat menyebabkan hiperbilirubinemia tidak jelas diketahui, namun dikatakan bahwa pada ASI ditemukan tingkat aktivitas sirkulasi lipoprotein lipase paling tinggi, yang ditunjukkan dengan peningkatan aktivitas $\beta$-glucoronidase dan mengandung $3 \alpha$, 20 $\beta$-pregnanediol. ${ }^{17,18}$ The American Academy of Pediatrics merekomendasikan anjuran untuk tetap menyusui untuk bayi dengan jaundice, dan menilai kecukupan menyusui dengan melihat urine neonatus, feses neonatus, dan berat badan. Suplementasi dengan susu formula dapat dipertimbangkan bila asupan ASI tidak memadai, terjadi penurunan berat badan yang berlebih, bayi tampak dehidrasi atau hiperbilirubinemia yang berat.,19

Faktor penyebab kelima yang ditemukan adalah asfiksia neonatorum dimana didapatkan pada 7 sampel dengan persentase $4.8 \%$. Penelitian yang dilakukan oleh Devi dkk tahun 2017 mendapatkan hasil adanya pengaruh yang kuat antara asfiksia neonatorum terhadap 
kejadian hiperbilirubinemia dengan nilai $\mathrm{p}$ sebesar 0.049, sama halnya dengan penelitian cross sectional oleh Saptanto dkk tahun 2016 yang mendapatkan bahwa terdapat hubungan yang signifikan antara asfiksia dengan hiperbilirubinemia dengan nilai $\mathrm{p}$ sebesar 0.0002. ${ }^{11,20}$ Bayi asfiksia dapat menghambat aktivitas Uridine Diphospate Glucoronytransferase (UDPGT) di hati yang menyebabkan meningkatnya bilirubin tak terkonjugasi. ${ }^{12}$ Namun pada penelitian Mojtahedi tahun 2018, Wijaya dkk tahun 2019, serta penelitian oleh Aynalem tahun 2020 tidak didapatkan hubungan yang signifikan antara asfiksia neonatorum dan kejadian hiperbilirubinemia. ${ }^{3,15,21}$

Faktor penyebab cephal hematome tidak didapatkan dalam sampel penelitian. Kemungkinan hal ini disebabkan oleh tidak adanya partus kala II lama selama setahun penelitian, yang meningkatkan risiko terjadinya cephal hematoma, atau dapat dikarenakan oleh memang tidak adanya pasien dengan cephal hematome yang kemudian mengalami hiperbilirubinemia. Penelitian Scrafford tahun 2013 menyebutkan bahwa Kala II lama memiliki hubungan yang kuat terhadap terjadinya jaundice. ${ }^{22}$ Sel darah merah pada bayi mengalami destruksi akibat trauma dan terakumulasi di cephal hematome, akan meningkatkan kadar bilirubin pada aliran darah bayi. ${ }^{23}$

\section{SIMPULAN}

Karakteristik faktor penyebab utama hiperbilirubinemia di RSIA Puri Bunda Tabanan yaitu inkompatibilitas ABO. Fator penyebab lain diikuti dengan prematuritas, breastfeeding jaundice, BBLR, sepsis neonatorum, breastmilk jaundice, asfiksia neonatorum. Tidak ada faktor penyebab cephal hematome yang didapatkan pada penelitian.

\section{KONFLIK KEPENTINGAN}

Penulis menyatakan bahwa penelitian ini bebas dari berbagai konflik kepentingan.

\section{ETIKA PENELITIAN}

Penelitian ini telah mendapatkan izin dari Komite Etik RSIA Puri Bunda.

\section{PENDANAAN}

Penulis menyatakan penelitian ini tidak mendapatkan bantuan dana dari pemerintah ataupun sektor swasta lainnya.

\section{KONTRIBUSI PENULIS}

Intan Astariani berkontribusi dalam konsep penelitian, pengumpulan data, analisis data, dan penulisan naskah publikasi. I Wayan Dharma Artana dan Ni Made Rini Suari berkontribusi dalam supervisi penelitian, analisis, analisis data, dan penulisan naskah publikasi.

\section{DAFTAR PUSTAKA}

1. Rohsiswatmo $\mathrm{R}$, Amandito $\mathrm{R}$. Hiperbilirubinemia pada Neonatus $>35$ Minggu di Indonesia: Pemeriksaan dan Tatalaksana Terkini. Sari Pediatri.2018;10(2):115-22.

2. Tavakolizadeh R, Izadi A, Seirafi G, Khedmat L, Mojtahedi SY. Maternal risk factors for neonatal jaundice: a hospital-based cross-sectional study in Tehran. 2018;28(3):257-64.

3. Wijaya FA, Suryawan WB. Faktor risiko kejadian hiperbilirubinemia pada neonatus di ruang perinatologi RSUD Wangaya Kota Denpasar. Medicina. 2019;50(2):357-64.

4. Lauer BJ, Spector ND. Hyperbilirubinemia in the Newborn. Pediatrics in Review. 2021;32(8): 341-8.

5. Santosa Q, Mukhson M, Muntafiah A. Evaluasi penggunaan fototerapi konvensional dalam taka laksana hiperbilirubinemia neonatal: efektif, tetapi tidak efisien. Sari Pediatri. 2020;21(6):377-85.

6. Hosea MK, Etika R, Lestari P. Hyperbilirubinemia treatment of neonatus in Dr. Soetomo Surabaya. Folia Medica Indonesiana. 2015;51(3):183-86.

7. Parwata WS, Putra PJ, Kardana M, Artana, WS, Sukmawati M. The characteristic of neonatal hyperbilirubinemia before and after phototherapy at Sanglah Hospital, Denpasar, Bali in 2017. Intisari Sains Medis. 2019;10(2):309-12.

8. Akgul S, Korkmaz A, Yigit S, Yurdakok M. Neonatal hyperbilirubinemia due to $\mathrm{ABO}$ incompatibility : does blood group matter?. The Turkish Journal of Pediatrics. 2013;55(5):506-9.

9. Maulida M, Sari RD, Mustofa S. Hubungan Kejadian Hiperbilirubinemia dengan Inkompatibilitas $\mathrm{ABO}$ pada Bayi Baru Lahir di RSUD Abdul Moeloek Provinsi Lampung. Medula. 2021;11(1):27-31.

10. Garosi E, Mohammadi F, Ranjkesh F. The Relationship between Neonatal Jaundice Maternal and Neonatal Factors. Iranian Journal of Neonatology. 2016;7(1):37-9.

11. Devi S, Vijaykumar B. Risk factors for neonatal hyperbilirubinemia: a case control study. International Journal of Reproduction, Contraception, Obstetrics and Gynecology. 2017;6(1):198-201.

12. Olusanya BO, Osibanjo FB, Slusher TM. Risk factor for severe neonatal hyperbilirubinemia in low and middle-income countries: a systematic review and meta-analysis. PloS ONE. 2015;10(2):4-10.

13. Centers for Disease Control and Prevention. Jaundice. 2020. Available at : https://www. cdc.gov/breastfeeding/breastfeeding-specialcircumstances/maternal-or-infant-illnesses/ jaundice.html

14. Halisanti O. Hubungan antara sepsis neonatorum dengan terjadinya ikterus neonatorum di RSUD Karanganyar. Fakultas Kedokteran Universitas Muhammadiyah Jakarta. 2017

15. Aynalem S, Abayneh M, Metaferia G, Demissie AG, Gidi NW, Demtse AG, dkk. Hyperbilirubinemia in preterm infants admitted to neonatal intensive care units in Ethiopia. Global Pediatric Health. 2020;7:1-8.

16. Puspita N. Pengaruh berat badan lahir rendah terhadap kejadian ikterus neonatorum di Sidoarjo. Jurnal Berkala Epidemiologi. 2018;6(2):174-81.

17. Huang MJ, Kua KE, Teng HC, Tang KS, Weng HW, Huang CS. Risk factors for severe hyperbilirubinemia in neonates. Pediatric Research. 2004;56(5):682-9.

18. Suradi R, Letupeirissa D. Air susu ibu dan ikterus. 2013. Available at : https://www.idai.or.id/cari?search= $\underline{\text { air }+ \text { susu+ibu+dan }+i k t e r u s \& i d=291}$

19. Muchowski KE. Evaluation and treatment of neonatal hyperbilirubinemia. American Family Physician. 2014;89(11):873-77.

20. Saptanto A, Kurniati ID, Khotijah S. Asfiksi meningkatkan kejadian hiperbilirubinemia patologis pada bayi di RSUD Tugurejo Semarang. Fakultas Kedokteran Universitas Muhammadiyah Semarang. 2016.

21. Mojtahedi SY, Izadi A, Seirafi G, Khedmat L, Tavakolizadeh R. Risk factors associated with neonatal sectional study from Iran. 2018;6(8):1387-93.

22. Scrafford. Incidence and risk factors for neonatal jaundice among newborns in Southern Nepal. Tropical Medicine and International Health. 2013;18(2):1317-28.

23. Birth Injury Help Center. Complications from cephalhematomas. Available at : https://www. birthinjuryhelpcenter.org/cephalohematomacomplications.html

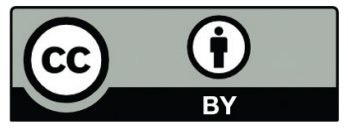

This work is licensed under a Creative Commons Attribution 